\title{
REPUBLIC OF MOLDOVA POWER ENERGY IN THE PANDEMIC
}

\author{
Corina Guțu-Chetrușca*, ORCID: 0000-0001-6090-4421, \\ Aurel Guțu, ORCID: 0000-0003-3290-623X \\ *Technical University of Moldova, 168 Stefan cel Mare blvd., Chisinau, Republic of Moldova \\ Corresponding author: Guțu-Chetrușca Corina, corina.gutu@tme.utm.md
}

Received: 10. 12. 2021

Accepted: 12.02 .2021

\begin{abstract}
The anti-COVID restrictions have resulted in a reduction of the total world energy consumption. At the same time, the transfer of the activities to home increased the household consumption of electricity by up to $30 \%$. In the Republic of Moldova, the total electricity consumption in 2020 decreased compared to 2019 by $0.22 \%$, while household consumption increased by $3.5 \%$. In the first quarter of 2021 , household consumption increased by $7.8 \%$, raising the share of household consumption to $45.5 \%$. Working from home has proven to be convenient for both employees and employers, so the trend is expected to remain after the pandemic crisis. In this context, a series of energy efficiency and renewable energy solutions in residential buildings are expected to be implemented.
\end{abstract}

Keywords: COVID-19, household electricity consumption, energy efficiency, renewable energy.

Rezumat. Restricțiile anti-COVID au condus la o reducere a consumului total de energie la nivel mondial. În același timp, transferul activităților la domiciliu a crescut consumul casnic de energie electrică cu până la $30 \%$. În Republica Moldova, consumul total de energie electrică în 2020 a scăzut față de 2019 cu 0,22\%, în timp ce consumul casnic a crescut cu $3,5 \%$. În primul trimestru al anului 2021, consumul casnic a crescut cu 7,8\%, ponderea acestuia ridicându-se la 45,5\%. Munca de acasă s-a dovedit a fi convenabilă atât pentru angajați, cât și pentru angajatori, așa că este de așteptat ca tendința să rămână după criza pandemiei. În acest context, apare necesitatea implementării la clădirile rezidențiale a unei serii de soluții de eficiență energetică și energie regenerabilă.

Cuvinte cheie: COVID-19, consum casnic de energie electrică, eficiență energetică, energie regenerabilă.

\section{Introduction}

Energy, being intercalated with all aspects of human activity, it does react to all the cataclysms and calamities that society is going through. In "Figure 1" is shown the recent rate of primary energy consumption changes, beginning with 1900 .

Thus, the major events that took place from the early twentieth century to the present days, including two world wars, several major economic crises, two flu pandemics (Spanish flu 1918-1920 and recently COVID-19) were followed by significant reductions in the growth rate of energy consumption, with the deepest decline seen after pandemics. 


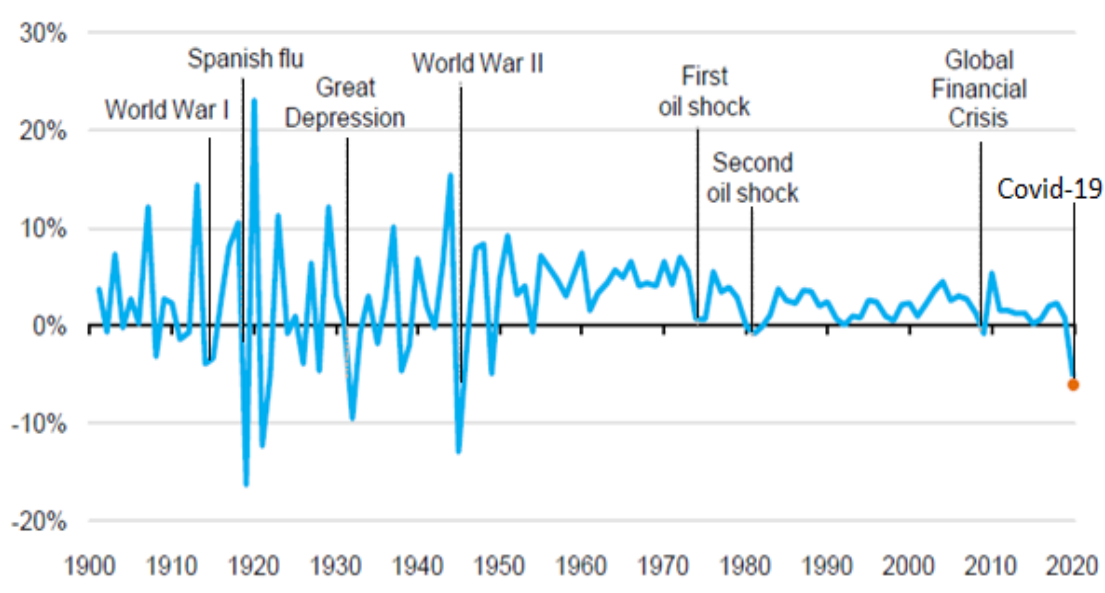

Figure 1. Rate of change in global primary energy demand, period 1900-2020 [1]

The SARS-CoV-2 virus originated in China in December 2019, by February 2020 spread to 41 countries, currently affecting 220 countries and territories, with the number of infected cases exceeding 220 million, and deceased reaching over 4.5 million [1, 2].

\section{The impact of the pandemic on the global energy sector}

In order to slow virus, spread, governments around the world have imposed restrictions on most social and economic activities. These included partial or complete lockdowns of schools and non-essential businesses and prohibition of public gatherings, social distance, travel bans, work-from-home policy. The limited restrictions reduce the weekly energy consumption by up to $15 \%$, the partial lockdown - by $10 \div 27 \%$, the total lockdown by $15 \div 33 \%$. Since first quarter of 2020 coal demand fell compared to the first quarter of 2019 by $8 \%$, oil demand by almost $5 \%$, gas demand by about $2 \%$, and the global energy demand fell by $3.8 \%$. Electricity demand during total lockdowns has decreased in several countries by $20 \%$ and above. In total, by 2020 the demand for electricity has decreased in China by $3 \%$, in the USA by $5 \%$, in the European Union by $5 \%$ [1]. Worldwide electricity consumption has decreased by 4\% [3]. Although lockdown measures have significantly reduced the demand for electricity due to the impact on the industrial sector and commercial buildings, however electricity consumption in the residential sector has increased during the full lockdown period by $11 \div 32 \%$ [4]. It is not only as a result of residents being confined to their apartments, as such, however also due to the transfer to work from home. At the same time, it can be noticed that the average daily peak power does not increase and the profile of the diurnal load curve in the morning hours is plateauing to the level of the maximum power that occurred in the similar period of time before the lockdown. The peak power of the sections feeding the different numbers of households also remained virtually unchanged $[5,6]$.

It is noticeable that, along with the total reduction in electricity demand, its production from renewable sources, which is less affected by restrictions and largely unaffected by demand, has increased worldwide in 2020 , compared to 2019 , by $6.3 \%$ [7]. The decrease in production from fossil fuels and increasing renewable energy have reduced $\mathrm{CO}_{2}$ emissions by $5.8 \%$ or almost $2 \mathrm{Gt}$ which constitutes the largest drop ever and almost five times the decline of 2009 following the global financial crisis [8]. If the increase in hydroelectric energy production is favorable for electric power systems, the variable wind and photovoltaic energies cause some difficulties for the system operators. 


\section{Pandemic and energy of the Republic of Moldova}

In the Republic of Moldova (Moldova) the first case of COVID-19 was confirmed on March 10, 2020. Restriction measures were initiated the same day. According to Decision no. 6 from March 10, 2020 of The National Public Health Emergency Commission of the Republic of Moldova a number of restrictions have been introduced such as: banning mass meetings, suspending the educational process within educational institutions, prohibiting access inside the subordinated institutions of the persons returned from COVID-19 infected regions, etc.

By Decision no. 9 from March 15, 2020, restrictions were introduced on the activity of commercial and public catering units. On May 15, 2020, a state of public health emergency was issued on the entire territory of the Republic of Moldova for the period May 16 - June 30, 2020, which was then extended periodically. During the summer months the National Public Health Emergency Commission lifted some restrictions, however in the fall, on November 27 the "Code Red" alert level was initiated in all administrative-territorial units of the republic. In January of 2021, again, some restrictions were lifted, unfortunately to be followed by reimposed State of emergency and the "Code Red" in February-March, which were enforced until April [8].

The vast majority of the country's national economy sectors have felt the negative impact of the pandemic. In the second quarter of 2020, the Gross Domestic Product decreased in real terms of $14 \%$. The most affected areas are those involving population interactions and movement, and also those in the informal economy. Thus, the decrease in the HoReCa sector was $66.2 \%$, theater, recreation; pleasure declined by $45.8 \%$, the decrease in the passenger transportation sector was above $50 \%$. At the same time, there was noticed an increase in computers and telecommunications equipment sales, which in the first half of the year registered an increase of $56 \%$ due to the transition to online schooling, and also the teleregime of work of some employees. There has also been a substantial increase in the information technology sector [9].

During the year 2020 among the republic population were registered approx. 145 thousand diseased and approx. 3 thousand deaths.

The epidemic evolution [8,9] and the consumption of electricity [10] between March 2020 and April 2021 are presented in "Figure 2".

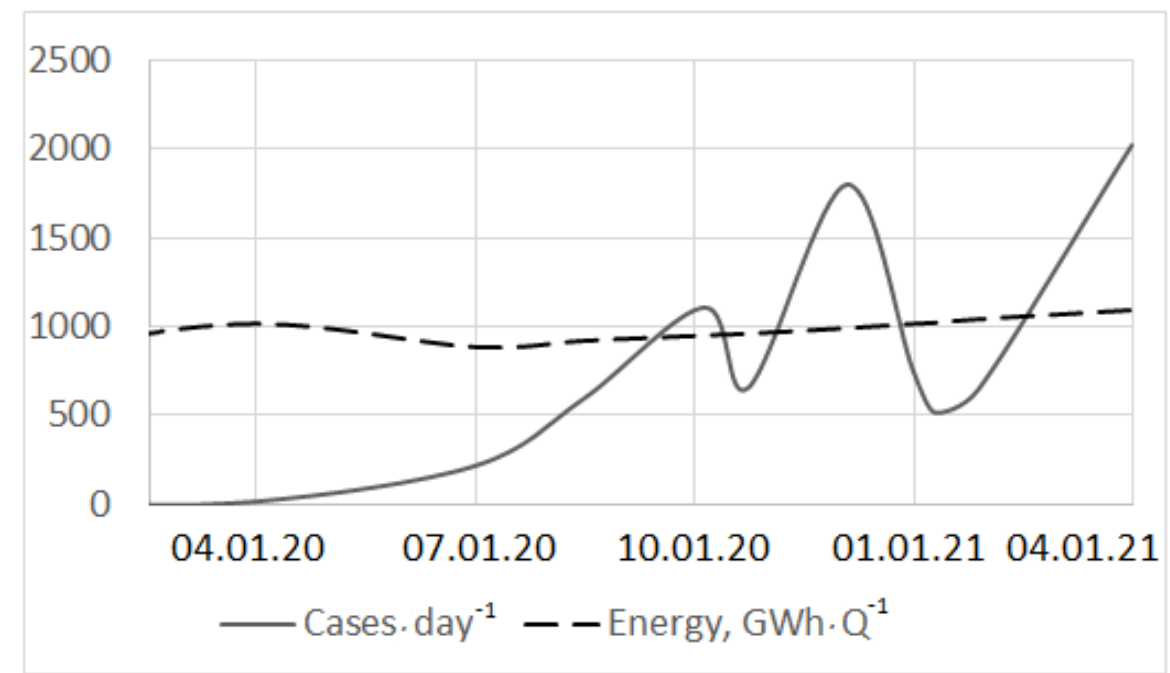

Figure 2. The development of the COVID-19 pandemic and the consumption of electricity in the Republic of Moldova. 
During that period of time, the pandemic went through three waves, each of them with increasing amplitudes: 1149 cases of newly diseased per day in October 2020, 1715 cases per day in December 2020 and 2132 cases per day in March 2021. With the introduction of restrictions, electricity consumption decreased in the second quarter of 2020, but subsequently, with the limiting of some restrictions and the declining attention to some of them, by ordinary citizens and, also, by the supervisory bodies, consumption increased slowly, both total and household consumption (see "Figure 3"). In the second half of 2020, both consumptions exceeded those of the previous year.

"Figure 4" shows the daily load curve of an electrical substation serving a neighborhood of 9 residential blocks. The curves are reflecting a day in mid-September with similar characteristics: average temperature $+16{ }^{\circ} \mathrm{C}$, mid-week. There is a marked increase in load during buisnes hours 8.00 to 19.00 , the peak of the load remaining virtually the same: $610 \mathrm{~kW}$ until the pandemic and $600 \mathrm{~kW}$ during the lockdown.

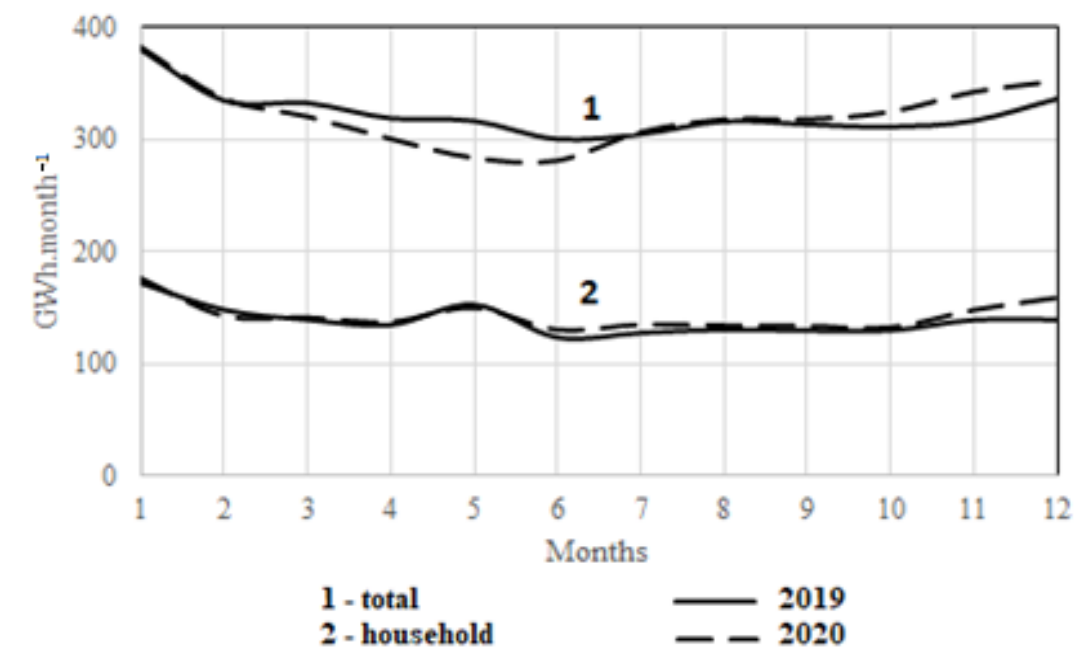

Figure 3. The dynamic of energy consumption in the Republic of Moldova in 2020 compared to 2019.

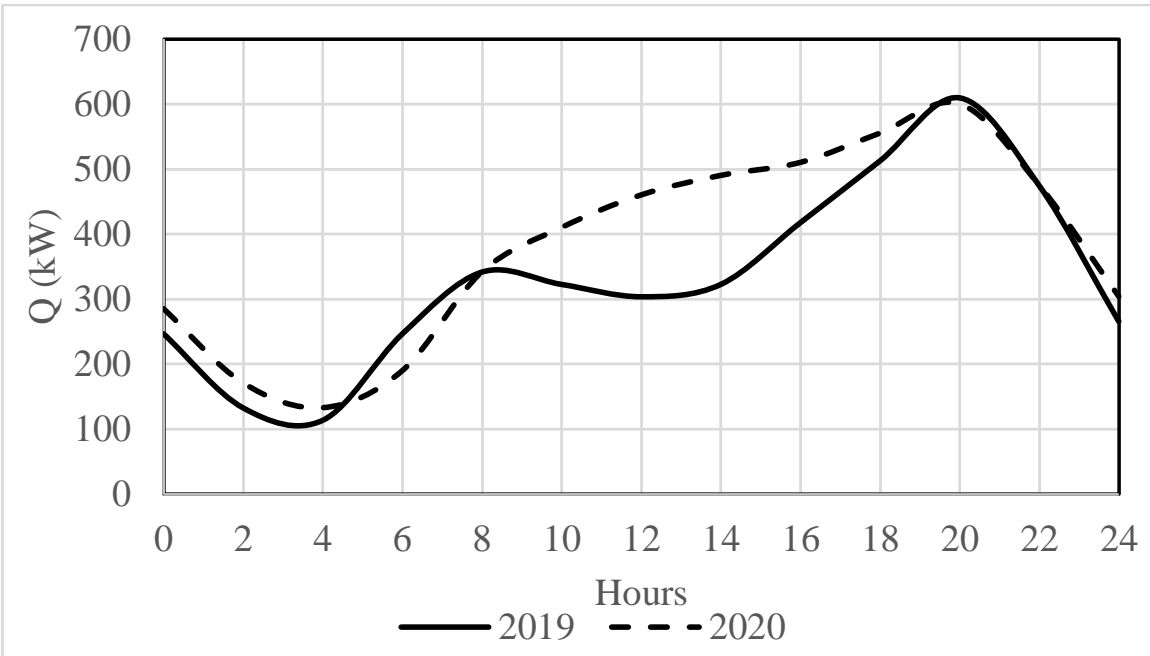

Figure 4. The daily load curve of a residential neighborhood in the lockdown and the same period of time prior the pandemic. 
The quarterly energy consumption in the evaluated time frame is presented in "Table 1" [10]. Total electricity use decreased insignificantly in 2020 compared to 2019, by only $0.22 \%$,

Table 1

Progression of electricity use in the Republic of Moldova during the 2019, 2020, 2021

\begin{tabular}{|c|c|c|c|c|c|c|}
\hline \multicolumn{2}{|l|}{ Quarter } & 1 & 2 & 3 & 4 & Annual \\
\hline \multirow{2}{*}{ Total (GWh) } & 2019 & 1072.64 & 936.69 & 920.09 & 945.69 & 3875.10 \\
\hline & 2020 & 1015.50 & 886.53 & 950.34 & 1014.2 & 3866.56 \\
\hline \multicolumn{2}{|c|}{ Variation 2020/2019 (\%) } & -5.33 & -5.36 & 3.29 & 7.24 & -0.22 \\
\hline \multirow{2}{*}{ Household (GWh) } & 2019 & 458.7 & 410.36 & 386.89 & 407.33 & 1663.28 \\
\hline & 2020 & 459.4 & 418.43 & 404.18 & 439.26 & 1721.27 \\
\hline \multicolumn{2}{|c|}{ Variation 2020/2019 (\%) } & 0.15 & 1.97 & 4.47 & 7.84 & 3.49 \\
\hline \multirow{2}{*}{ Household share (\%) } & 2019 & 42.76 & 43.81 & 42.05 & 43.07 & 42.92 \\
\hline & 2020 & 45.24 & 47.20 & 42.53 & 43.31 & 44.52 \\
\hline \multicolumn{2}{|l|}{ Total 2021 (GWh) } & 1089.9 & 970.9 & & & \\
\hline \multicolumn{2}{|c|}{ Variation $2021 / 2020$ (\%) } & 7.33 & 9.52 & & & \\
\hline \multicolumn{2}{|c|}{ Household 2021 (GWh) } & 495.4 & 437.7 & & & \\
\hline \multicolumn{2}{|c|}{ Variation 2021/2020 (\%) } & 7.8 & 4.7 & & & \\
\hline \multicolumn{2}{|c|}{ Household share 2021 (\%) } & 45.5 & 45.1 & & & \\
\hline
\end{tabular}

while household consumption increased by $3.5 \%$. The high rate of household power consumption stands out, it was $42.9 \%$ in 2019 and $44.5 \%$ in 2020 while in the European Union the rate is $31 \%$ [11], and in the USA - 22\% [12]. In the first quarter of 2021, household use has increased by $7.8 \%$ compared to the respective period of time in 2020 , the total power use by $7.3 \%$, with the household consumption rate reaching $45.5 \%$.

Table 2

Sources of electricity acquisition in the Republic

\begin{tabular}{lccc}
\hline Sources & $\begin{array}{c}\mathbf{2 0 1 9} \\
\text { (GWh) }\end{array}$ & $\begin{array}{c}\mathbf{2 0 2 0} \\
\text { (GWh) }\end{array}$ & $\begin{array}{c}\mathbf{2 0 2 0 / 2 0 1 9} \\
\text { (\%) }\end{array}$ \\
\hline Import & 3509.1 & 3418.4 & -2.58 \\
\hline Fossil fuels & 659.6 & 723.4 & 9.67 \\
\hline Hydro & 58.3 & 46.7 & -19.90 \\
\hline Wind & 36.915 & 50.138 & 35.8 \\
\hline PV & 1.437 & 3.275 & 127.9 \\
\hline Biogas & 28.748 & 27.793 & -3.3 \\
\hline Total & 4301.9 & 4269.8 & -0.75 \\
\hline
\end{tabular}

The insignificant reduction in consumption, compared to other countries', is mainly explained by two factors: first the high rate of household consumption and second the fact that most factories in the Republic of Moldova are part of food industry and cannot be kept in lockdown.

The structure of electricity purchasing in the republic is presented in "Table 2". The difference between the amount of energy purchased and delivered is accounted for the losses in the networks and is less than $10 \%$. The share of renewable sources in electricity production, which constitutes more than $15 \%$ of the domestic product, has increased by $8.5 \%$. This grow 
was due to photovoltaic panels (127.9\%) and wind installations (35.8\%). The drought in 2020 reduced the production of hydraulic energy by $19.9 \%$ and of the biomass-based energy by $3.3 \%$. The production of other primary energy sources has undergone changes within the limits of variation in previous years. Electricity imports decreased by $1.3 \%$ [13 - 15].

\section{Post-pandemics solutions}

Working from home has proven to be convenient for both employees and employers. Employers have reduced their expenses with the maintenance and workspaces servicing, on the other hand employees are relieved from wasting time and money and from the inconveniences of traveling to work and back. In addition to that, for many employees, working from home is more convenient than in often crowded office buildings. That is why this change is expected to continue after the pandemic crisis is resolved. In this setting, the main focus is on residential buildings where a series of energy efficiency and renewable energy solutions are suggested, in order to improve living conditions and reduce energy consumption and $\mathrm{CO}_{2}$ emissions, such as:

- Increasing the efficiency of home appliances, computers and office equipment used in working from home;

- Increasing the efficiency of the ventilation and air conditioning systems equipment of the work spaces in order to reduce the energy consumption and to improve the quality of the indoor air;

- Maximum use of natural lighting;

- Thermal rehabilitation of buildings to reduce both heat input in summer and heat loss in winter, especially in buildings heated by electricity or heat pumps;

- Using of smart thermostats to adjust temperature settings according to changing in buildings occupancy patterns, especially when a large number of residents are staying at home;

- Implementing umbrellas and blinds use to optimize the heat exchange of the buildings with the environment, as well as the access to daylight, depending on the season and the particular heating and cooling needs;

- Implementing of integrated photovoltaic systems for buildings on the roofs, walls, windows, shading devices; these systems can meet the entire electricity demands of the residential buildings;

- Installation of combined photovoltaic and thermal (PV / T) collector systems for the simultaneous production of electricity and residential hot water.

Increasing use of electricity storage installations, both systemic and individual (neighborhoods, individual house), as the increase in the rate of variable renewable energy (solar and eolian) will increasingly complicate the work of system operators. Storage will increase the resilience of the energy supply to ensure its availability at the scene during network outages.

These solutions will be needed both for existing buildings, repairs, reconstructions and rehabilitations, and especially for the design of new buildings, with a tendency towards "green houses". To implement them, it is necessary to involve decision-makers to include them in energy programs that are targeting residential buildings. In the Republic of Moldova, energy efficiency programs and renewable sources are applied to social objects: schools, kindergartens, orphanages. It is necessary to expand these programs to include residential buildings. Energy literacy of this population of this area is also needed. For the Republic of 
Moldova, which imports over $80 \%$ of electricity and in which domestic electricity consumption is close to half of total consumption, these actions will give a significant result.

\section{Conclusions}

The restrictions on social and economic activities during the pandemic reduced total electricity consumption. However, it increased household consumption, both by keeping tenants at home and by switching to work and education from home. Work from home has proved convenient for both employees and employers, which is why it is expected to persist even after the resolution of the pandemic crisis. As a result, there rises the need to apply a series of energy efficiency and renewable energy solutions to residential buildings. Increasing the rate of variable renewable energy involves the development of electricity storage installations. In the Republic of Moldova, it is rational to expand the existing energy efficiency and renewable sources programs, on social objects, and on residential buildings.

\section{References}

1. Global Energy Review 2020. The impacts of the Covid-19 crisis on global energy demand and $\mathrm{CO}_{2}$ emissions https://en.wikipedia.org/wiki/COVID-19_pandemic

2. Global Energy Review 2021 Key findings Assessing the effects of economic recoveries on global energy demand and $\mathrm{CO}_{2}$ emissions in 2021

3. Krarti M., Aldubyan M. Review analysis of COVID-19 impact on electricity demand for residential buildings. Renewable and Sustainable Energy Reviews. Volume 143, June 2021, 110888. https://www.sciencedirect.com/science/article/abs/pii/S1364032121001829

4. Jiang P., Van Fan Y., Klemeš J. J.. Impacts of COVID-19 on energy demand and consumption: Challenges, lessons and emerging opportunities. https://www.ncbi.nlm.nih.gov/pmc/articles/PMC7834155/

5. Bielecki S., Skoczkowski T., Sobczak L., Buchoski J., Maci Ł. and Du kat P. Impact of the Lockdown during the COVID-19 Pandemic on Electricity Use by Residential Users. https://www.mdpi.com/journal/energies

\section{WEB references:}

6. https://ourworldindata.org/electricity-mix

7. https://www.iea.org/reports/global-energy-review-2021/co2-emissions

8. MD coronavirus information. https://gov.md/ro/content/informatii-privind-coronavirus

9. https://www.worldometers.info/coronavirus/

10. ANRE monitoring reports. https://www.anre.md/rapoarte-de-monitorizare-3-73

11. What are the major uses of electricity? http://shrinkthatfootprint.com/how-do-we-use-electricity.

12.Ürge-Vorsatz D. ENERGY END-USE: BUILDINGS. https://iiasa.ac.at/web/home/research/FlagshipProjects/Global-Energy-Assessment/GEA_Chapter10_buildings_hires.pdf

13. Statistical yearbook. https://statistica.gov.md/public/files/publicatii electronice/

14. Energy balance: balanta_energetica/BE_editia_2020_rom.pdf.

15. Analysis: the impact of the coronary crisis on the economy of the Republic of Moldova. https://agora.md/stiri. 